Esta publicación cientifica en formato digital es continuidad de la revista impresa ISSN-Versión Impresa 0798-1406 / ISSN-Versión on line 2542-3185Depósito legal pp
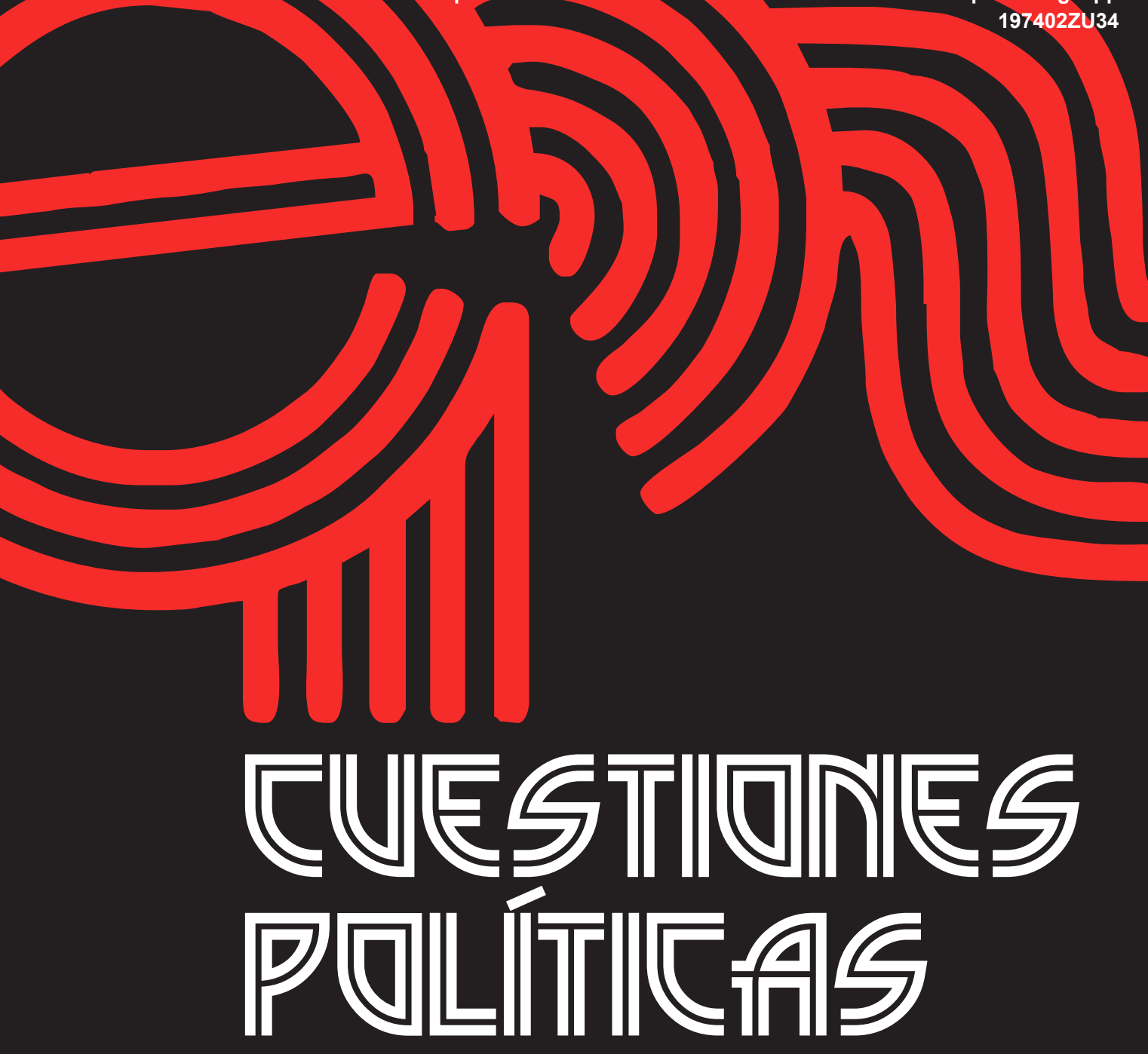

Instituto de Estudios Políticos y Derecho Público "Dr. Humberto J. La Roche" de la Facultad de Ciencias Jurídicas y Políticas de la Universidad del Zulia Maracaibo, Venezuela
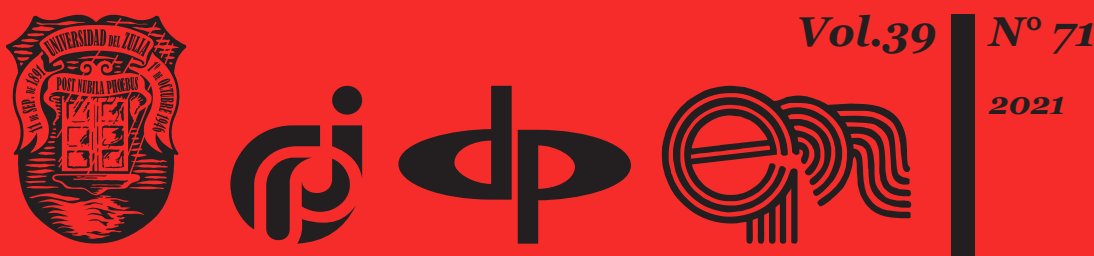


\title{
Protection of the Rights of Persons Who Have Lost Their Jobs Because of the Spread of COVID-19
}

\author{
DOI: https://doi.org/10.46398/cuestpol.3971.13
}

\author{
Volodymyr Ya. Kyian * \\ Ruslan V. Kolosov ** \\ Nataliia $V$. Bilianska *** \\ Hanna V. Churpita **** \\ Igor M. Dovban *****
}

\section{Abstract}

The aim of the study was to identify possible ways to protect the rights of people who have lost their jobs due to the spread of COVID-19, and thus to analyze the effectiveness of international experience. The information in this article is obtained by three methods: direct observation, comparison, and analysis of the content of the documents. However, at the beginning of the pandemic, the regulation of guarantees and social protection of the rights of dismissed people was not enough. In the future, job seekers must learn the skills of the most popular professions and specialties: in the field of healthcare, in the field of digital technology and transportation. In turn, government programs should promote the reconversion of the most vulnerable groups in the labor market through free courses and online learning programs, and assistance in the employment of people with disabilities. It is concluded that, during the pandemic, most countries modified their labor regulations and provided labor subsidies to preserve jobs. However, during recovery after the pandemic, governments in all countries must change their approach.

Keywords: rights protection; dismissal of employees; spread of COVID-19; labor law; international situation.

* Doctor of Law, Head of Department of Civil Law Disciplines, Dnipropetrovsk State University of Internal Affairs. ORCID ID: https://orcid.org/oooo-0002-8517-9876

** Candidate of Law, Associate Professor of the Department of Civil, Labor Law and Social Security Law, faculty 3, Donetsk Law Inst Ute of the Ministry of Internal Affairs of Ukraine. ORCID ID: https://orcid. org/0000-0002-3080-729X

*** Candidate of Law, Professor of Department of Civil Law Disciplines, National Academy of Internal Affairs. ORCID ID: https://orcid.org/oooo-0002-1650-5500

**** Doctor of Law, Professor of Department of Civil Law Disciplines, National Academy of Internal Affairs. ORCID ID: https://orcid.org/oooo-0003-3915-347X

***** Candidate of Law, Acting Chairman of the Board, PJSC "Kyiv - Dnipro intersectoral industrial railway transportation company". ORCID ID: https://orcid.org/oooo-ooo1-8590-2334 


\section{Protección de los derechos de las personas que han perdido su trabajo debido a la propagación del COVID-19}

\section{Resumen}

El objetivo del estudio fue identificar posibles formas de proteger los derechos de las personas que han perdido su empleo por la propagación del COVID-19 y, por lo tanto, analizar la efectividad de la experiencia internacional. La información de este artículo se obtiene mediante tres métodos: observación directa, comparación y análisis del contenido de los documentos. Sin embargo, al inicio de la pandemia, la regulación de garantías y protección social de los derechos de las personas despedidas no fue suficiente. En el futuro, los solicitantes de empleo deben aprender las habilidades de las profesiones y especialidades más populares: en el campo de la atención médica, en el campo de la tecnología digital y el transporte. A su vez, los programas gubernamentales deben promover la reconversión de los grupos más vulnerables en el mercado laboral a través de cursos gratuitos y programas de aprendizaje en línea, y ayudar en el empleo de personas con discapacidad. Se concluye que, durante la pandemia, la mayoría de los países modificaron sus regulaciones laborales y proporcionaron subsidios laborales para preservar los empleos. Sin embargo, en el curso de la recuperación después de la pandemia, los gobiernos de todos los países deben cambiar su enfoque.

Palabras clave: protección de derechos; despido de empleados; propagación del COVID-19; derecho laboral; situación internacional.

\section{Introduction}

The crisis of the COVID-19 virus has led to massive job losses and complicated the operation of the labour market around the world. According to the National Statistics Service, the number of employed people aged 15 to 70 decreased by $4 \%$, the number of applications to the employment service increased by $33.1 \%$, and the demand for jobs decreased by $28 \%$ one year after the beginning of the coronavirus epidemic (Fund of Compulsory State Social Insurance of Ukraine, 2021). Anti-epidemiological containment measures have led to a significant drop in employment worldwide. For example, these figures were the following: in Mexico - 40\%, in Korea and Japan - 8-9\% (OECD, 2020). In the United States, the number of applications to the employment service 4 times (Fowler, 2020) exceeded the 1982 record in one week of 2020, and the number of vacancy announcements decreased by $30 \%$ (Shuai et al., 2021). 
Due to the pandemic, remote work "from home" using digital technologies has become the norm for many countries and will continue to be a requirement of employers. In general, the number of new vacancies registered with public employment services has declined sharply, although demand for certain occupations and industries has increased: agriculture and food production, health care, logistics and IT services. By 2030, the labour market is expected to reduce demand for retail, food and manufacturing workers and increase demand for transport and health workers. As a result, jobseekers need to learn the skills of in-demand occupations and specialties that will have a higher salary level: in the field of health care, digital technology, and transportation.

Dismissed employees face numerous employment difficulties: they have psychological problems; low level of motivation; reduced working time of the public employment service and other pandemic-related restrictions. The lack of adequate social protection for employees dismissed through COVID-19 has a negative impact on the labour market, people and society (PRI, 2020). However, due to a coordinated international policy response, the impact of coronavirus on employment has been significantly reduced (ILO, 2020c). Developed countries have taken large-scale measures and additional steps to preserve jobs to be terminated: they facilitated the mass transition to teleworking for persons whose physical presence in the workplace is not mandatory (OECD iLibrary, 2020); introduced wage subsidies for employers; introduced monthly subsidies to dismissed employees; provided additional funds to enterprises that did not have liquidity (Larue, 2020).

Combating the spread of COVID-19 at the company's workplaces plays an important anti-epidemiological role, as it protects not only workers but also the society around them, as well as preserves the viability of doing business (ILO, 2020d). This poses a need for additional jobs for doctors and those who oppose the spread of infectious diseases, while for other professions the spread of COVID-19 leads to a decreased need for workers, even in the form of dismissal. The paradox of the legal protection of people dismissed in connection with the spread of COVID-19 is that lawyers who can protect them also lose their jobs.

In the real business world, the protection of the rights of individuals to keep working while staying in safe workplaces should be a priority of public policy and social activities, and not be resolved by workers alone after their redundancy or dismissal. Despite the difficulties in labour relations, the majority of the working population remains in their jobs at the risk of losing their jobs at any time.1. 
Volodymyr Ya. Kyian, Ruslan V. Kolosov, Nataliia V. Bilianska, Hanna V. Churpita y Igor M. Dovban Protection of the Rights of Persons Who Have Lost Their Jobs Because of the Spread of COVID-19

\section{Expected results}

The study will provide further development and improvement of ways and means of protecting the rights of persons dismissed during COVID-19 taking into account the experience of other countries.

\section{Topicality}

By the end of 2020, 16 million people had lost their jobs due to the pandemic. Low-skilled, low-paid and temporary workers were the first to be dismissed. Work is essential not only for their families, but also affects the size of the pension (European Commission, 2021). At the same time, self-employed and informal workers who have lost their jobs due to the virus are less socially protected than those who work officially because they do not have access to sick leaves and other forms of social unemployment benefits (ILO, 2020b). According to the survey, 88\% of Europeans believe that in the context of a pandemic, the most pressing problem for citizens is everyone's access to the labour market (Data.europa.eu., 2020).

The pandemic crisis has accelerated the processes of digitalisation and automation of production. Almost all jobs with close physical contact were eliminated in a short time, and some will still experience a similar effect. Work during the pandemic was supported by the rapid introduction of new digital solutions: video conferencing and remote exchange of electronic documents. By 2030, more than 100 million workers in eight countries (China, France, Germany, India, Japan, Spain, the United Kingdom and the United States, which together make up half of the world's population) are expected to change occupations. The problem of retraining and the transition of workers to new professions is long-term. At the same time, policymakers can play an important role in expanding the digital infrastructure and supporting retraining, ensuring that lifelong learning becomes a reality and distance work becomes the norm. The concept of "workplace" should not have fundamental formal differences between the place of work in the office or at home (McKinsey Global Institute, 2021). It has been found that workers who are unable to do certain tasks at home are more likely to lose their jobs in the future (Adams-Prassl et al., 2020).

Many countries have actively implemented unprecedented measures and targeted programs to overcome the negative processes in the labour market associated with the dismissal of employees. However, no changes have been made to Ukraine's labour law (Verkhovna Rada of Ukraine, 2021a) to strengthen the legal protection of workers after their dismissal during a pandemic (Free legal aid, 2020). As before, in case of violation of labour rights regarding illegal dismissal and in case of official employment, people should write complaints to the employer to the State Labour Department or go to court (Legal 100, 2020). 
That is, apart from the ways and means of protecting workers from coronavirus-related dismissal that existed prior to COVID-19, no other ways and means has been introduced. With regard to the protection of dismissed persons, the system of labour legislation and state social insurance in case of unemployment was not "ready" to respond to the pandemic crisis, therefore this issue is topical and needs comprehensive study.

\section{Aim of the research}

The aim of the study is to identify possible ways to protect the rights of people who have lost their jobs due to the spread of COVID-19, analyse the effectiveness of international experience and propose promising changes to labour law in this matter.

The main research objectives included establishing measures have been introduced in the labour market; what programs were adopted by the state employment services; what short-term and long-term measures are planned in the labour market in order to protect job seekers during quarantine.

\section{Methods}

The input data for this study were information obtained from scientific papers and articles, generalizations of international human rights organizations. In total, more than 70 official sources were used. At the same time, the main empirical data were obtained using three methods: direct observation, comparison, and analysis of the content of documents governing the protection of the rights of persons dismissed during the pandemic at the national level and in other countries.

The regulatory documents and programmes governing the procedure and features of protection of the rights of persons dismissed during COVID-19 were reviewed in the course of direct observation. Typical programmes of state employment services for overcoming unemployment were identified. The significance of specific programmes and active measures aimed at protecting the rights of persons dismissed during COVID-19 is proved.

During the observation of modern scientific opinion, it was established that there is a need for further development of legislative regulation of telecommuting, as well as additional support for those dismissed during the coronavirus pandemic.

It is established how the countries ensure the protection of the rights of persons dismissed during quarantine through the method of comparison. The public employment service is unable to respond to the changes in the labour market without a sufficient amount of reserve fund in a crisis. In addition, it was found that at the national level, telecommuting is enshrined only a year after the start of the pandemic. 
The information posted on social networks, scientific journals and on news websites was studied in the course of the analysis of the content of various documents. The programmes and ways chosen by the state employment services in the labour market to reduce unemployment were established.

\section{Results}

The right of citizens to social protection in case of unemployment is provided by the Constitution of Ukraine and is guaranteed by the obligatory state social insurance (Verkhovna Rada of Ukraine, 1996). The Law of Ukraine "On Employment" provides that in case of unemployment everyone has the right to social protection, in particular: to receive unemployment benefits in accordance with the social insurance programme, obtain information and counselling services, training, advanced training for employment at a proper position, receive special guarantees in connection with changes in the organization of production and labor (Verkhovna Rada of Ukraine, 1991).

The duration of unemployment benefits is not reduced for persons who resigned voluntarily during the quarantine period without good reason or by agreement of the parties, but it does not exceed 270 calendar days. It is recommended to apply directly to the employer or to the state employment service for a job search (State Employment Center, n.d.). In addition, Ukraine, as a signatory to the Employment Promotion and Protection against Unemployment Convention, should follow the following recommendations for the unemployed: take full account of them; increase the amount and duration of unemployment benefits; reduce the duration for job search, including for part-time workers; provide them with medical care (Verkhovna Rada of Ukraine, 2008). As a result of the pandemic, employees and employers experienced gaps in labour legislation that needed to be addressed immediately to curb the spread of the virus and maintain a normal work schedule. National procedures or special bodies should be established to plan, monitor and adjust job return plans (Lukianova and Zaitseva, 2021).

However, the national labour legislation was finally amended in 2021 in response to the pandemic, but the bill itself was registered only in early September 2020 (Verkhovna Rada of Ukraine, 2021b). From now on, the Labour Code regulates the concepts of telecommuting and homebased work in considerable detail, as well as the differences between them (Adams-Prassl et al., 2020).

When considering the basic skills listed in the current vacancy announcements in the studied countries (Australia, Canada, New Zealand, 
the UK and the US), the increasing demand for workers with technical skills in the medical sector such as "emergency and intensive care" or "first aid to patients" was found. Therefore, in the short term, it is important for the government to support the development of skills that increase people's livelihoods by satisfying efforts in the labour markets. In the long run, governments should support the low-skilled and imaginary worker through effective government retraining and retraining programmes (OECD, 2021a).

The European Skills Agenda has identified a new and dynamic approach to 2025 on skills policy for able-bodied people aged 16 to 74 . European countries, businesses, social partners and other stakeholders should work to increase adult participation in learning and improve the level of learning, especially digital and advanced skills. During 2021-2027, the European Social Fund, with a budget of EUR 86 milliard, as well as EUR 4.6 milliard of the Erasmus+ programme, will remain an important source of funding for national retraining programmes (European Commission, 2020a). Besides, the European Commission recommends to gradually move away from emergency measures and consider the following strategic (not short-term) policies in the labour market: incentives to support and start a business; opportunities for advanced training and retraining; strengthening support from youth employment services and workers most affected by the pandemic. The Commission continues to support Member States' efforts to increase the availability of care services for children and other dependents through investments from the European Social Fund+, the European Regional Development Fund, the InvestEU Programme and the European Agricultural Fund for Rural Development (Eurofound, 2021).

In Hong Kong, an analysis of the impact of telecommuting on business success has shown that the government should consider the following in the short term: introducing formal telecommuting guidance for employees and employers; accounting for expected employees; determination of minimum requirements for technology training for a virtual office; and technical means for telecommuting. In the long run, the government should focus on: reviewing the opportunities of telecommuting to become the new norm; revision of the current labour legislation and extension of labour insurance policies to work from home; encouraging small and mediumsized businesses by providing subsidies and other incentives; strengthening the current distance business programme; promoting the practice of employment, taking into account the fact of having a family (Vyas and Butakhieo, 2021). The use of working time while working from home can be more productive and beneficial to people's health (Hallman et al., 2021).

After the start of the pandemic, regulatory changes provided for additional obligations of employers regarding the amount of severance pay, dismissal and hiring. For example, Gabon provided for the payment of 
additional compensation to dismissed workers, which was not previously provided for in the Labour Code (ILO, 2020a). In Suriname, the Ministry of Labour recommended that the employment service worker hold joint consultations between the parties and set up additional contacts of the Labour Inspection Hotline, where dismissed workers can apply if their rights are violated (Covid-19, 2020). In Azerbaijan, in order to prevent unjustified dismissals or dismissals of private sector employees, the government has provided daily monitoring through an electronic job protection system (ILO, 2020a). In the Australian context, economic measures in the form of financial support for those affected by the pandemic have provided positive health outcomes by reducing the number of people experiencing financial stress due to job loss (Griffiths et al., 2021).

Some countries also adapted their employment services during the pandemic: they introduced new digital tools for online mediation in the labour market in order to facilitate successful matches between workers and employers; created new training and retraining programmes for dismissed employees (Lukianova and Zaitseva, 2021). For example, the Russian Federation has introduced a remote procedure for employment, registration of unemployed citizens and the payment of compensation, as well as increased unemployment benefits (Verkhovna Rada of Ukraine, 2021b). Brazil, in turn, has introduced remote work with the transition to a "home office", doubled the amount paid to men who are the head of the family and created a digital platform to help and facilitate the hiring of health workers in the fight against the pandemic (KPMG, 2020).

Lithuania and Germany have also expanded access to employment for low-skilled older people, and the Republic of Korea has favoured employment for young adults and increased the number of new employees in public institutions (ShieldGeo, 2021). In Anguilla, with 23.5\% of the population suffering from poverty, the government has offered free training courses to more than 500 employers in the field of tourism to overcome the crisis (COVID-19: The Anguillian Response, 2020). Antigua and Barbuda paid severance pay for retraining to citizens who once worked for the regional airline (Office of The Prime Minister Antigua and Barbuda, 2021). In the UK, the government has introduced a scheme to provide financial support to companies to create jobs and train young people who have cash loans (Gov.ua, 2020b). In Indonesia, a pre-employment program aimed at the development and retraining of the unemployed has been introduced in the budget: tuition fees; incentive payment for job search; incentive payment for participation in social surveys (Bahar, 2020). In December 2020, the Government of the Maldives allocated additional funds to the unemployed, and in February 2021 announced a new programme to train young people in tourism and construction (The President's Office Republic of Maldives, 2021). Zimbabwe has announced that it will involve the private sector in the creation of training and retraining centres, labour-intensive public works 
programmes, etc. as part of the 2021 National Development Plan (ITUC CSI IGB, 2021). Sweden provided a partial financial compensation of $60 \%$ of the tuition fee (Myklebust, 2020).

In some countries, labour market support costs depend on the current unemployment rate, making the employment system more responsive to changing labour market needs. In Denmark, the Netherlands and Switzerland, the size of the budget for labour market measures automatically increases as unemployment increases. At the same time, some countries still plan to increase the number of public employment service staff with the increase in the number of unemployed, in particular: France, Great Britain, Luxembourg and Turkey (OECD, 2021b). In addition, the Slovak government has introduced the "First Aid" scheme to support self-employed workers who have been forced to close down.

The measures implemented in the labour market were divided according to the number of countries as follows (Table 1): about 50\% of countries implemented regulatory changes to labour regulations or provided wage subsidies, about $25 \%$ of countries conducted training or the transition to reduced working hours.

Table 1. Distribution of implemented measures in the labour market (author's own development)

\begin{tabular}{l|c}
\hline Labour market measures & $\begin{array}{c}\text { Number of countries that have } \\
\text { implemented measures }\end{array}$ \\
\hline $\begin{array}{l}\text { Regulatory changes to the labour } \\
\text { regulations }\end{array}$ & 125 \\
\hline Wage subsidies & 120 \\
\hline Training activities (learning new skills) & 76 \\
\hline Transition to reduced working hours & 75 \\
\hline
\end{tabular}

Only 16 countries have implemented a full set of four measures: Antigua and Barbuda, Australia, Austria, Belgium, Brazil, Canada, Chile, France, Greece, Honduras, Mauritius, the Netherlands, Norway, Serbia, the Slovak Republic, and Uzbekistan; at least one of these measures was implemented by about $80 \%$ of countries. Active measures in the labour market are aimed at increasing the likelihood of employment in the short term and include: training, employment promotion, sheltered and supported employment and rehabilitation, direct job creation and promotion of start-up projects. In addition, subsidised social security contributions (245 programmes), unemployment benefits (172 programmes) and paid sick leave (134 programmes) are widely used. Pension-related measures in some countries, 
such as Ecuador, allow for the early withdrawal of accumulated pensions (World Bank, 2021).

However, due to the pandemic, most public employment services have completely closed their offices to their clients (e.g., Germany, France, Denmark, Croatia, Spain, Estonia, Lithuania, Greece, and Poland). To avoid unnecessary visits to employment centres and vocational training centers, channels and digital tools have been introduced to provide consultations. A wide range of communication channels is used for remote counselling: telephone, Skype (Estonia, Sweden, Denmark), electronic communication programs, and to group meetings and webinars through audio and video conferences (Netherlands, Portugal). In Slovenia, consulting services were provided by regular website operators.

However, due to the pandemic, most public employment services have completely closed their offices to their clients (for example, Germany, France, Denmark, Croatia, Spain, Estonia, Lithuania, Greece and Poland). The channels and digital tools have been introduced to provide consultations in order to avoid unnecessary visits to employment centres and vocational training centres. A wide range of communication channels is used for remote counselling: telephone, Skype (Estonia, Sweden, Denmark), electronic communication programmes, group meetings and webinars through audio and video conferences (Netherlands, Portugal). In Slovenia, consulting services were provided by on-duty website operators.

The services of a psychologist, medical tests and skills tests (to decide on retraining measures) were not provided remotely. At the same time, there were restrictions on the provision of consultations due to the fact that the staff had not been previously trained (Austria, Slovakia, Croatia) (European Commission, 2020c). Specialists from the Public Employment Service also provided online correspondence services in electronic form (in Finland), with digital access for people with hearing or vision problems through the free mobile application RogerVoice (in France) (TE-palvelut, 2021).

Thus, many countries have comprehensively implemented their programmes on the activities in the labour market mainly in two ways: the activities of public employment services (Semaine Europeenne Pour, 2020) and active measures in the labour market (OECD, 2021b; Eurofound, 2020a). The programmes implemented in the labour market will be schematically presented in Figure 1. 


\section{Activities of public employment}

Advising and managing job seeker (Netherlands, Portugal, Slovenia, Suriname);

Financial assistance in finding a job (Denmark, the Netherlands, Switzerland), but Mexico and Spain, on the contrary, have reduced their labour costs for the unemployed);

Brokerage for employers in "hot" vacancies (for example, Germarry created an online platform to help agricultural companies find local harvest workers, Estonia has ShareForce One platform); Provision of administrative benefits in order to preserve the jobs (Azerbaijan).
Active measures in the labour market

Creation of development and new skills training (internship) funds (Italy, Ireland, Luxembourg, the Netherlands, Portugal, Austria, Lithuania, Germarry), but Slovakia and Croatia suspended all training activities; Initiative employment programmes (Estonia, the Netherlands, Spain, Malta). Ukrainian govemment has announced a programme to create 500,000 jobs;

Supported employment of people with disabilities (Italy, Ireland, Spain, France, Portugal, Poland, Slovakia, Croatia);

Subsidies for job creation (Netherlands, Romania Lithuania, Hungary), Sweden, Denmark, Belgium, the Netherlands alreacty had additional anti-crisis funds before the pandemic;

Start-up financing (Finland, Austria);

Subsidies to the unemployed for employment (Cyprus, Greece, France, Bulgaria, Spain, Great Britain)

\section{Figure 1. The programmes implemented in the labour market (author's own development)}

At the same time, employment under a permanent contract has been introduced in Portugal (Cabinet of Ministers of Ukraine, 2020). To help the unemployed adjust to the labour market, the French Employment Service provides access to free or paid employment courses in various professions and specialties, as well as webinars (Estamos On, 2020). Besides, the Public Employment Service in Germany has started providing information on online learning opportunities, including free courses (Pole-Emploi, 2021).

The vast majority of public employment services have suspended the introduction of incentives for employment. Only a minority of them continue to launch specific programmes and implement new measures, mainly for vulnerable groups. However, stimulating employment compared to other measures in the labour market, such as training and retraining, has longer-term prospects (KOFA, n.d.). Besides, the facts show that it is more advantageous to retrain existing employees instead of dismissing them and then finding new people (European Commission, 2020b).

Unemployment assistance programmes implemented by employment services are presented in Table 2 (Unemployment assistance programmes). 


\begin{tabular}{|c|c|c|}
\hline $\begin{array}{l}\text { Name of the } \\
\text { programme }\end{array}$ & $\begin{array}{c}\text { Countries where it } \\
\text { is introduced }\end{array}$ & Peculiarities \\
\hline $\begin{array}{l}\text { Reducing the } \\
\text { duration of } \\
\text { processing } \\
\text { applications for } \\
\text { unemployment } \\
\text { benefits }\end{array}$ & $\begin{array}{l}\text { Spain, France, and } \\
\text { Finland }\end{array}$ & $\begin{array}{l}\text { Norway and Finland have reduced } \\
\text { the time for receiving temporary } \\
\text { unemployment benefits and } \\
\text { extended the period for paying } \\
\text { unemployment benefits. In Norway, } \\
\text { the pay period for dismissal has been } \\
\text { reduced from } 15 \text { to } 2 \text { days. The state } \\
\text { bears the costs starting from day } 3 \\
\text { (Sneader and Singhal, 2021). }\end{array}$ \\
\hline $\begin{array}{l}\text { Increasing } \\
\text { the amount of } \\
\text { unemployment } \\
\text { benefits }\end{array}$ & Ireland and Norway & $\begin{array}{l}\text { In Ireland, workers who lost their } \\
\text { jobs due to the Covid-19 crisis } \\
\text { received increased unemployment } \\
\text { benefits in connection with the } \\
\text { pandemic of EUR 1,40O per month, } \\
\text { and those seeking - EUR } 812 \text { per } \\
\text { month. In Ukraine, unemployment } \\
\text { benefits have been increased by UAH } \\
\text { 350 for the period of quarantine } \\
\text { (Eurofound, 2020b). }\end{array}$ \\
\hline $\begin{array}{l}\text { Extension of } \\
\text { unemployment } \\
\text { benefits for } \\
\text { several months, } \\
\text { despite the } \\
\text { availability of } \\
\text { vacancies }\end{array}$ & $\begin{array}{l}\text { Germany, France, } \\
\text { Greece, Portugal, } \\
\text { Luxembourg, USA }\end{array}$ & $\begin{array}{l}\text { In response to the pandemic, all U.S. } \\
\text { states provided } 13 \text { additional weeks } \\
\text { of unemployment benefits from the } \\
\text { federal budget and several weeks } \\
\text { from state budgets (Ministry of } \\
\text { Economy of Ukraine, 2020). }\end{array}$ \\
\hline $\begin{array}{l}\text { Simplification } \\
\text { of the procedure } \\
\text { for applying for } \\
\text { unemployment } \\
\text { benefits by means } \\
\text { of an online } \\
\text { programme or a } \\
\text { programme by } \\
\text { phone }\end{array}$ & $\begin{array}{l}\text { France, Germany, } \\
\text { Spain, Italy, Spain, } \\
\text { Cyprus, Greece, } \\
\text { Estonia, the } \\
\text { Netherlands, Croatia, } \\
\text { Russia, Romania and } \\
\text { Ukraine (Center on } \\
\text { Budget and Policy } \\
\text { Priorities, 2021). }\end{array}$ & $\begin{array}{l}\text { Aimed at reducing the administrative } \\
\text { burden. These programmes are valid } \\
\text { even without a signature, additional } \\
\text { documents can be scanned or sent by } \\
\text { mail if necessary. }\end{array}$ \\
\hline
\end{tabular}

In the period from March 20, 2020, to May 14, 2021, 3,333 social protections were applied in 222 countries or territories. Most social protection measures (55\%) are provided in the form of social assistance, in particular in the regions of Eastern Europe, Central Asia and highincome countries. At the same time, in 186 countries social assistance was provided in cash. About $17 \%$ of the world's population has received at least one Covid-19-related money transfer. Only a minority of countries have the high flexibility of financial resources to respond to changes in the labour market. For example, by the first wave of COVID-19, in early 2020, Israel and Switzerland had already prepared crisis management plans in the labour market, which proved useful (Free legal aid, 2020). Croatia, Finland and Slovenia believe that the adaptability and commitment of 
employment service staff, as well as the ability to redistribute tasks, have been key to their success in tackling COVID-19 in 2020 (Gov.ua, 2020a). At the same time, targeted activities for imaginary groups should be organised at the company level first aid available online or quick financial assistance for those who have partially or completely lost their way (OECD iLibrary, 2020).

\section{Discussion}

Countries with more flexible rules have been able to review their policies more quickly. About one third of the countries had very general framework laws on employment before the crisis, so the introduction and change of employment was practically implemented without the adoption of additional emergency laws. For example, in the Czech Republic, Malta and New Zealand, there was no need for the government or ministry to bring regulations into line with the crisis conditions. In countries with less flexible labour regulations, adaptation has been carried out without the involvement of parliament (Tušl et al., 2021). As a result of the pandemic, the countries of the Anglo-Saxon legal family (USA, Great Britain) suffered the most in the labour market than the countries of the Romano-Germanic legal family (Germany) (Adams-Prassl et al., 2020).

The results of monitoring the activities of the Government of Ukraine after the pandemic indicate the need for further implementation of a comprehensive approach to the legislative regulation of telework, as well as additional support for those whose employment and welfare have suffered most from the crisis (Publications Office of the EU, 2020).

Restrictions on the pandemic have forced automation of the workplaces in many industries after dismissals, and therefore, many firms will not return to the previous production process, even after the jobs are safe. At the same time, women with medium and low wages will feel the greatest risk of the negative impact of production automation (Filipchuk and Lomonosova, 2020).

Due to the pandemic, many industries in the market are unlikely to fully recover for some time, and many companies will emerge from this crisis in a negative financial position. New policy decisions should promote active labour market measures, including: investment in advanced skills development; temporary employment and transition to related specialties; increasing the volume of staff and qualifications of employment services, using the allocated funds.

To do this, it is necessary to develop and implement labour standards suitable for future work. However, the labour world is constantly changing, 
especially due to digitization (European Commission, 2021). More than $80 \%$ of companies surveyed in 2018 have already used digital learning tools, and approximately $70 \%$ of companies consider the use of digital learning tools as an important tool to keep up with the times (Chernoff and Warman, 2021).

There is a direct link between the level of education, the results of practical training and the chances of employment. Many European countries do not provide training or retraining for those who have already received their first education. Women's labour can gain popularity in the labour market through education reforms and the introduction of childcare programmes. Control and testing of the actual skills of the working population remains low. The use of short-term schemes in work has already mitigated the negative effects of the pandemic on the labour market (KOFA, 2020).

Due to the Covid-19 crisis, the implementation of training activities seems difficult, as it is carried out only by digital means via the Internet. The potential for work from home in developed economies is only 20-25 percent of workers who could work remotely five days a week (ILO, 2020b).

Legal regulation of guarantees and social protection of the rights of persons dismissed from work at the beginning of the pandemic was not sufficient. Depending on income levels, countries allocated wage subsidies and labour regulations. Due to the prepared plans in case of crisis and rapid response to the pandemic, the countries of the predominantly RomanoGermanic legal family (Germany, Austria, Switzerland) suffered less losses in the labour market than the Anglo-Saxon family (USA, UK). The advantage for the country is the provision of reserve funds in the budget in proportion to the unemployment rate.

In order to protect the rights of those dismissed at the national level, programmes to combat unemployment are being implemented rather slowly. Such forms of work as telework and work at home are enshrined in law only a year after the start of the pandemic, but the introduction of a national digital system for receiving unemployment benefits is positive. Automation, digitisation and efficiency in the processing of applications for unemployment benefits avoids physical contact of the unemployed with the public employment service and speeds up the process of processing applications.

\section{Conclusion}

During the pandemic, most countries amended their labour regulations and provided labour subsidies to preserve jobs. However, in the course of recovery after the COVID-19 pandemic, governments in all countries need 
to shift the focus from short-term immediate income and employment support to the long-awaited return to work of large numbers of unemployed by increasing labour demand. Although most European countries do not promote retraining for those who already have an education. To achieve this goal, governments and businesses need to: anticipate the current needs of the labour market; promote redistribution between industries; promote comprehensive development, training and retraining through free online courses and programmes; provide material support to the most vulnerable groups (women, youth, the elderly, unskilled workers).

In the short term, it is advisable to make changes to labour legislation: the introduction of the procedure for official management of remote work for employees and employers; determination of minimum requirements for digital technology training programmes in the context of a virtual office. In the long run, the government should focus on: reviewing existing labour legislation and ensuring the extension of remote work insurance policies to work from home; promoting the practice of hiring women, taking into account the availability of children and providing child care programmes (accessibility of social babysitting). Besides, the government should promote employment in safe remote working conditions for all those who can switch to this form of work by providing for appropriate rules in a standard employment contract.

The State Employment Service should develop a plan for crisis management in the labour market to protect the rights of those who lost their jobs due to the pandemic, which should include: increasing the staff of highly qualified personnel; consulting and case management of job seekers; providing financial and intermediary assistance in finding a job from among "hot" vacancies. Unemployment assistance programmes for the quarantine period should provide for the extension of unemployment benefits, despite the availability of vacancies.

The active measures to help the unemployed should include: the use of short-term work schemes; provision of funds for the development and training on new skills in the budget; technological support of employment for people with disabilities; provision of subsidies to employers to create new jobs; active provision of financial assistance and creation of incentives to support the implementation of start-ups of newly established enterprises; allocation of targeted subsidies to the unemployed.

\section{Bibliographic References}

ADAMS-PRASSL, Abigail; BONEVA, Teodora; GOLIN, Marta; RAUH, Christopher. 2020. Inequality in the Impact of the Coronavirus Shock: Evidence from Real Time Surveys. Available online. In: https://www. 
Volodymyr Ya. Kyian, Ruslan V. Kolosov, Natalïa V. Bilianska, Hanna V. Churpita y Igor M. Dovban Protection of the Rights of Persons Who Have Lost Their Jobs Because of the Spread of COVID-19

inet.econ.cam.ac.uk/working-paper-pdfs/wp2018.pdf. Consultation date: $18 / 05 / 2021$.

BAHAR. 2020. Pre-employment card as a tool to develop Indonesian human resources during COVID-19 outbreak. Available online. In: https:// www.bahar.co.id/index.php/whats-new/whats-new/pre-employmentcard-tool-develop-indonesian-human-resources-during-covid-19. Consultation date: 21/05/2021.

CABINETOF MINISTERS OF UKRAINE. 2020. Action plan to create conditions for increasing employment. Available online. In: https://www.kmu.gov. ua/news/plan-zahodiv-po-stvorennyu-umov-dlya-pidvishchennyazajnyatosti-naselennya. Consultation date: 18/05/2021.

CENTER ON BUDGET AND POLICY PRIORITIES. 2021. Policy Basics: How Many Weeks of Unemployment Compensation Are Available? Available online. In: https://www.cbpp.org/research/economy/how-manyweeks-of-unemployment-compensation-are-available. Consultation date: 19/05/2021.

CHERNOFF, Alex; WARMAN, Casey. 2021. Down and out: Pandemic-induced automation and labour market disparities of COVID-19. Available online. In: https://voxeu.org/article/pandemic-induced-automation-andlabour-market-disparities-covid-19. Consultation date: 20/05/2021.

COVID-19. 2020. Important consultation between employer and employee during the COVID crisis. Available online. In: https://covid-19.sr/ overleg-werkgever-en-werknemer-van-belang-tijdens-covid-crisis/. Consultation date: 22/05/2021.

COVID-19: THE ANGUILLIAN RESPONSE. 2020. Anguilla expands vacation bubble concept for phase two reopening. Available online. In: https:// beatcovid19.ai/anguilla-expands-vacation-bubble-concept-for-phasetwo-reopening/. Consultation date: 22/05/2021.

DATA.EUROPA.EU. 2020. Special Eurobarometer 509: Social issues. Directorate-General for Communication. The official portal for European data. Available online. In: https://data.europa.eu/data/datasets/ s2266_94_2_509_eng?locale=en. Consultation date: 22/05/2021.

ESTAMOS ON. 2020. Employment and Economy Support. Available online. In: https://covid19estamoson.gov.pt/apoios-ao-emprego-e-economia/. Consultation date: 18/05/2021.

EUROFOUND. 2020a. Employment protection and retention. Available online. In: https://static.eurofound.europa.eu/covid19db/categories/ Employment_protection_and_retention.html Consultation date: 18/05/2021. 
EUROFOUND. 2020b. Temporary amendment to the regulation of layoffs. Available online. In: https://static.eurofound.europa.eu/covid19db/ cases/NO-2020-12_720.html?utm_source=externalDashboard\&utm_ medium=powerbi\&utm_campaign=covid-19. Consultation date: 18/05/2021.

EUROFOUND. 2021. Commission's Recommendation on Effective Active Support to Employment. Available online. In: https://static.eurofound. europa.eu/covid19db/cases/EU-2021-10_1784.html. Consultation date: 18/05/2021.

EUROPEAN COMMISSION. 2020a. Commission presents European Skills Agenda for sustainable competitiveness, social fairness and resilience. Available online. In: https://ec.europa.eu/social/ main.jsp?langId $=$ en\&catId $=89 \&$ furtherNews $=$ yes\&newsId $=9723$. Consultation date: 22/05/2021.

EUROPEAN COMMISSION. 2020b. Communication from the commission to the European parliament, the council, the European economic and social committee and the committee of the regions a Union of Equality: Gender Equality Strategy 2020-2025. COM/2020/152 final. Available online. In: https://eur-lex.europa.eu/legal-content/EN/ TXT/PDF/?uri=CELEX:52020DC0152\&from=EN. Consultation date: 23/05/2021.

EUROPEAN COMMISSION. 2020c. European Network of Public Employment Services PES measures and activities responding to Covid-19. Available online. In: https://economix.org/a55ets/publications/ PES\%20Network\%20study\%20-\%20PES\%20measures\%20and\%20 activities\%20responding\%20to\%20Covid-19-1.pdf. Consultation date: 20/05/2021.

EUROPEAN COMMISSION. 2021. The European pillar of social rights action plan. Luxembourg: Publications Office of the European Union. Available online. In: https://ec.europa.eu/social/ BlobServlet?docId=23696\&langId=en. Consultation date: 12/05/2021.

FILIPCHUK, Liliana; LOMONOSOVA, Natalia. 2020. Coronavirus and telecommuting: what the state has done. Available online. In: https:// cedos.org.ua/researches/koronavirus-i-dystantsiina-robota-shchozrobyla-derzhava. Consultation date: 23/05/2021.

FOWLER, Damian. 2020. Millions of people around the world have lost their jobs amid the current Covid-19 crisis. How should you handle your emotional reaction? Available online. In: https://www.bbc.com/ worklife/article/20200327-unemployment-during-coronavirus-thepsychology-of-job-loss. Consultation date: 16/05/2021. 
Volodymyr Ya. Kyian, Ruslan V. Kolosov, Nataliia V. Bilianska, Hanna V. Churpita y Igor M. Dovban

FREE LEGAL AID. 2020. Dismissal during quarantine: how employees can protect their rights. Available online. In: https://www.legalaid.gov.ua/ novyny/zvilnennya-pid-chas-karantynu-yak-pratsivnykam-zahystytysvoyi-prava/. Consultation date: 09/05/2021.

FUND OF COMPULSORY STATE SOCIAL INSURANCE OF UKRAINE. 2021. Resolution of the Board of the Fund of Compulsory State Social Insurance of Ukraine in Case of Unemployment №12 of 28.05.2021. Available online. In: https://www.dcz.gov.ua/sites/default/files/ postanova_no_12.pdf. Consultation date: 20/05/2021.

GOV.UA. 2020a. State Employment Service: the procedure for registration and receipt of unemployment benefits has been simplified for the period of quarantine. Available online. In: https://www.kmu.gov.ua/ news/derzhsluzhba-zajnyatosti-na-period-karantinu-sproshchenoproceduru-reyestraciyi-ta-otrimannya-dopomogi-po-bezrobittyu. Consultation date: 20/05/2021.

GOV.UA. 2020b. Support for businesses and self-employed people during coronavirus. Kickstart Scheme. Available online. In: https://www. gov.uk/government/collections/kickstart-scheme. Consultation date: 22/05/2021.

GRIFFITHS, Daniel; SHEEHAN, Luke; VAN VREDEN, Caryn; PETRIE, Dennis; GRANT, Genevieve; WHITEFORD, Peter; SIM, Malcolm; COLLIE, Alex. 2021. "The Impact of Work Loss on Mental and Physical Health During the COVID-19 Pandemic: Baseline Findings from a Prospective Cohort Study" In: Journal of Occupational Rehabilitation. Vol. 31, pp. 455-462.

HALLMAN, David; JANUARIO, Leticia; BERGAMIN MATHIASSEN, Svend Erik; HEIDEN, Marina; SVENSSON, Sven; BERGSTRÖM, Gunnar. 2021. "Working from home during the COVID-19 outbreak in Sweden: effects on 24-h time-use in office workers" In: BMC Public Health. Vol. 21, p. 528.

INTERNATIONAL LABOUR ORGANIZATION (ILO). 2020a. COVID-19 and the world of work. Country policy responses. Available online. In: https://www.ilo.org/global/topics/coronavirus/regional-country/ country-responses/lang--en/index.htm. Consultation date: 17/05/2021.

INTERNATIONAL LABOUR ORGANIZATION (ILO). 2020b. COVID-19 and the world of work: Impact and policy responses. ILO Monitor 1st Edition. Available online. In: https://www.ilo.org/wcmsp5/groups/public/--dgreports/---dcomm/documents/briefingnote/wcms_738753.pdf. Consultation date: 20/05/2021. 
INTERNATIONAL LABOUR ORGANIZATION (ILO). 2020c. COVID-19: Protecting workers in the workplace. Available online. In: https://www. ilo.org/global/about-the-ilo/newsroom/news/WCMS_738742/lang-en/index.htm. Consultation date: 18/05/2021.

INTERNATIONAL LABOUR ORGANIZATION (ILO). 2020d. In the face of a pandemic: Ensuring safety and health at work. Geneva: ILO. Available online. In: https://www.ilo.org/wcmsp5/groups/public/---ed_protect/--protrav/---safework/documents/publication/wcms_742463.pdf. Consultation date: 21/05/2021.

ITUC CSI IGB. 2021. Timefor8: Unions' actions at national level - Zimbabwe. Available online. In: https://www.ituc-csi.org/unions-succeedin-ensuring-decent-work-in-zimbabwe-development-plan-20212025?lang=en. Consultation date: 17/05/2021.

KOFA. 2020. KOFA study 3/2019: Digital education in companies. Available online. In: https://www.kofa.de/service/bestellshop/detailseite/news/ kofa-studie-32019-digitale-bildung-in-unternehmen. Consultation date: 17/05/2021.

KOFA. n.d. The way to the right e-learning offer. Available online. In: https:// www.kofa.de/dossiers/digital-aus-und-weiterbilden/digitale-medienin-der-betrieblichen-weiterbildung/passende-e-learning-angebote. Consultation date: 19/05/2021.

KPMG. 2020. Brazil. Government and institution measures in response to COVID-19. Available online. In: https://home.kpmg/xx/en/home/ insights/2020/04/brazil-government-and-institution-measures-inresponse-to-covid.html. Consultation date: 17/05/2021.

LARUE, Bruno. 2020. "Labor issues and COVID-19" In: Canadian Journal of Agricultural Economics. Vol. 68, No. 2, pp. 231-237.

LEGAL 100. 2020. Protection of labor rights during quarantine. Available online. In: https://legal10o.org.ua/zapis-vebinaru-zahist-trudovihprav-pid-chas-karantinu/. Consultation date: 22/05/2021.

LUKIANOVA, Natalia; ZAITSEVA, Olena. 2021. Coronavirus pandemic: legal mechanisms to protect labor and social rights of workers. Available online. In: http://rv.dsp.gov.ua/wpcontent/uploads/2021/02/lhsi_ pandemya_koronavrusu.pdf. Consultation date: 09/05/2021.

MCKINSEY GLOBAL INSTITUTE. 2021. The future of work after COVID 19. Available online. In: https://www.mckinsey.com/ /media/ mckinsey/featured\%20insights/future\%20of\%20organizations/ the $\% 20$ future\%20of\%20work\%20after\%20covid\%2019/mgi_ 
Volodymyr Ya. Kyian, Ruslan V. Kolosov, Natalïa V. Bilianska, Hanna V. Churpita y Igor M. Dovban Protection of the Rights of Persons Who Have Lost Their Jobs Because of the Spread of COVID-19

the\%2ofuture\%20of\%20work\%20after\%20covid-19_report-f. pdf?shouldIndex=false. Consultation date: 09/05/2021.

MINISTRY OF ECONOMY OF UKRAINE. 2020. The minimum unemployment benefit has been increased from UAH 650 to UAH 1,000. Available online. In: https://www.me.gov.ua/News/Detail?lang=uk-UA\&id=71de347d427b-46c8-bcfab302941c4095\&title=MinimalnuDopomoguPoBezrobi ttiuPidvischenoZ650-GrnDo1000-Grn. Consultation date: 15/05/2021.

MYKLEBUST, Jan Petter. 2020. International student numbers up 13\% despite COVID-19. University World News. Available online. In: https://www. universityworldnews.com/post.php?story=20200930054856301. Consultation date: 17/05/2021.

OECD ILIBRARY. 2020. Employment Outlook 2020: Worker Security and the COVID-19 Crisis. Available online. In: https://www.oecdilibrary.org/sites/1686c758-en/index.html?itemId=/content/ publication/1686c758-en\#section-d1e451. Consultation date: 09/05/2021.

OECD. 2020. The impact of the COVID-19 pandemic on jobs and incomes in G2O economies. Available online. In: https://www.ilo.org/wcmsp5/groups/ public/---dgreports/---cabinet/documents/publication/wcms_756331. pdf. Consultation date: 16/05/2021.

OECD. 2021a. OECD Policy Responses to Coronavirus (COVID-19). An assessment of the impact of COVID-19 on job and skills demand using online job vacancy data. Available online. In: https://www.oecd. org/coronavirus/policy-responses/an-assessment-of-the-impact-ofcovid-19-on-job-and-skills-demand-using-online-job-vacancy-data20fffoge/\#contactinfo-d7e2443. Consultation date: 22/05/2021.

OECD. 2021b. OECD Policy Responses to Coronavirus (COVID-19). Scaling up policies that connect people with jobs in the recovery from COVID-19. 29 April 2021. Available online. In: https://www.oecd.org/coronavirus/ policy-responses/scaling-up-policies-that-connect-people-with-jobs-inthe-recovery-from-covid-19-a91d2087. Consultation date: 27/05/2021.

OFFICE OF THE PRIME MINISTER ANTIGUA AND BARBUDA. 2021. Facebook post. Available online. In: https://www.facebook.com/ OPMAntiguaBarbuda/posts/843686889763148. Consultation date: 20/05/2021.

POLE-EMPLOI. 2021. Available online. In: https://www.actuformation.poleemploi.org/. Consultation date: 17/05/2021. 
PRI. 2020. COVID-19 Resources. Theme 1: protecting workers' rights through the Covid-19 crisis. Available online. In: https://www.unpri.org/covid19-resources/theme-1-protecting-workers-rights-through-the-covid-19crisis/6342.article. Consultation date: 28/05/2021.

PUBLICATIONS OFFICE OF THE EU. 2020. European Network of Public Employment Services PES measures and activities responding to Covid-19: Survey-based study. Available online. In: https://op.europa. eu/en/publication-detail/-/publication/a5b46760-e743-11ea-ad25o1aa75ed71a1/language-en. Consultation date: 17/05/2021.

SEMAINE EUROPEENNE POUR. 2020. Roger Voice. Available online. In: https://www.semaine-emploi-handicap.com/roger-voice. Consultation date: 21/05/2021.

SHIELDGEO. 2021. Work Permits. Available online. In: https://shieldgeo. com/poland-immigration-and-work-permits/. Consultation date: 20/05/2021.

SHUAI, Xiaobing; CHMURA, Christine; STINCHCOMB, James. 2021. "COVID-19, labor demand, and government responses: evidence from job posting data” In: Business Economics. Vol. 56, pp. 29-42.

SNEADER, Kevin; SINGHAL, Shubham. 2021. The next normal arrives: Trends that will define 2021- and beyond. Available online. In: https:// www.mckinsey.com/featured-insights/leadership/the-next-normalarrives-trends-that-will-define-2021-and-beyond. Consultation date: 20/05/2021.

STATEEMPLOYMENTCENTER.n.d.Socialprotectionincaseofunemployment. Available online. In: https://www.dcz.gov.ua/publikaciya/socialnyyzahyst-u-razi-nastannya-bezrobittya. Consultation date: 09/05/2021.

TE-PALVELUT. 2021. TE services in the corona situation. Available online. In: https://www.te-palvelut.fi/en/special-pages/corona-situation. Consultation date: 10/06/2021.

THE PRESIDENT'S OFFICE REPUBLIC OF MALDIVES. 2021. President's speeches. unofficial translation of the presidential address, 2021. Available online. In: https://presidency.gov.mv/Press/Article/24297. Consultation date: 22/05/2021.

TUŠL, Martin; BRAUCHLI, Rebecca; KERKSIECK, Philipp; BAUER, Georg. 2021. "Impact of the COVID-19 crisis on work and private life, mental well-being and self-rated health in German and Swiss employees: a cross-sectional online survey" In: BMC Public Health. Vol. 21, p. 741. 
VERKHOVNA RADA OF UKRAINE. 1991. Law of Ukraine on Employment. Available online. In: https://zakon.rada.gov.ua/laws/show/5067-17/ print. Consultation date: 09/05/2021.

VERKHOVNA RADA OF UKRAINE. 1996. Constitution of Ukraine. Available online. In: https://zakon.rada.gov.ua/laws/ show/254\%Do\%BA/96\%Do\%B2\%D1\%80/print. Consultation date: 10/05/2021.

VERKHOVNA RADA OF UKRAINE. 2008. Convention on Employment Promotion and Protection against Unemployment. Available online. In: https://zakon.rada.gov.ua/laws/show/993_182\#Text. Consultation date: 09/05/2021.

VERKHOVNA RADA OF UKRAINE. 2021a. Labor Code of Ukraine. Available online. In: https://zakon.rada.gov.ua/laws/show/322-08\#Text. Consultation date: 09/05/2021.

VERKHOVNA RADA OF UKRAINE. 2021b. On modification of some legislative acts of Ukraine concerning improvement of legal regulation of remote, home work and work with application of a flexible mode of working hours. Available online. In: https://zakon.rada.gov.ua/laws/show/1213IX\#Text. Consultation date: 09/05/2021.

VYAS, Lina; BUTAKHIEO, Nantapong. 2021. "The impact of working from home during COVID-19 on work and life domains: an exploratory study on Hong Kong” In: Policy Design and Practice. Vol. 4, pp. 59-76.

WORLD BANK. 2021. Social Protection and Jobs Responses to COVID-19: A Real-Time Review of Country Measures. Available online. In: https://openknowledge.worldbank.org/bitstream/ handle/10986/33635/Social-Protection-and-Jobs-Responses-toCOVID-19-A-Real-Time-Review-of-Country-Measures-May-14-2021. pdf?sequence $=25$ \&isAllowed $=y$. Consultation date: 21/05/2021. 
Vol. 39 N $^{\circ} 71$

Esta revista fue editada en formato digital y publicada en diciembre de 2021, por el Fondo Editorial Serbiluz, Universidad del Zulia. Maracaibo-Venezuela 